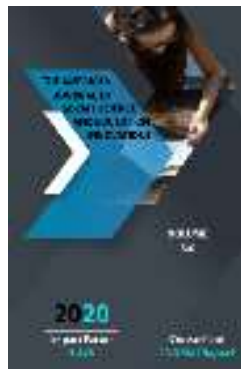

Journal Website: http://usajournalshub.c om/index,php/tajssei

Copyright: Original content from this work may be used under the terms of the creative commons attributes 4.0 licence.

\section{Geochemical Criteria Of Ore Content Of Metasomatites Of The Urtalik Deposit (North Nuratau)}

\author{
D.I. Jumaniyozov \\ Junior Researcher, Institute Of Geology And Geophysics Named After Kh.M.Abdullaev, \\ Tashkent, Uzbekistan
}

\author{
A.M. Musayev \\ Senior Researcher, Institute Of Geology And Geophysics Named After Kh.M.Abdullaev, \\ Tashkent, Uzbekistan \\ S.Y. Nematullayev \\ Chief Geologist, State Unitary Enterprise "Samarkandgeology", Samarkand, Uzbekistan
}

\title{
ABSTRACT
}

On the studied site of the Urtalik ore deposit, rare, rare-earth and polymetallic mineralization is shown. Rare elements zirconium and niobium can have restite character which gets a steady state at the recrystallization of ore-bearing minerals. At the same time a rare element zirconium and a rare-earth element ytterbium selectively concentrate in the zircon and apatite respectively.

\section{KEYWORDS}

North Nuratau, rare-earth elements, mineralisation, metasomatite, metallizing process, granosyenite; galena, sphalerite, Charmitan ore field.

\section{INTRODUCTION}

Relevance of study of the relationship between ore changes at the Urtalik deposit can be justified by the statement of S.S. Smirnov, which is the greatest expert on ore deposits, that "one of the main ways of progress in the study of ore deposits is here, in the area of the most thorough qualitative and quantitative study of ore changes". In accordance with the idea of H.M. Abdullaev about the genetic relationship of mineralization with intrusions can be considered the Charmitan ore field a vivid example of this hypothesis. Here we can make sure that for gold mineralization and metasomatism, a regularity is their spatial and genetic relationship with the most differentiated late alkaline and acidic appearance of intrusive hypabyssal 
magmatism as a result of a long evolution of the magma chamber.

\section{MAIN PART}

The problem of studying metasomatites, rare and noble metals of the Uraltalik deposit, dividing them into facies differences in the mineralogical and geochemical criteria of their zonality, elucidating the spatial position of the identified metasomatic formations, makes it relevant to study near-ore changes in this object in accordance with S.S. Smirnov that "one of the main paths of progress in the study of ore deposits takes place here, in the field of the most thorough qualitative and quantitative study of ore changes". In accordance with the idea of H.M. Abdullaev on the genetic relationship of mineralization with intrusions, the Charmitan ore field can be considered, including the Urtalik deposits, as a vivid example of this hypothesis. Here you can make sure that for gold mineralization and metasomatism, the regularity is their spatial and genetic relationship with the most differentiated late alkaline and acidic manifestations of intrusive hypabyssal magmatism as a result of a long evolution of the magma chamber.

The Urtalik gold deposit, formerly called Promejutochnoe, is located on the southern slopes of the central part of the ridge. Northern Nuratau and administratively belongs to the Koshrabad district of the Samarkand region of the Republic of Uzbekistan. The deposit area is $2.8 \mathrm{~km} 2$, located on the southeastern tip of the Koshrabad granitoid massif (C3-P1 according to I.Kh. Khamrabaev; P2T1 according to D.L. Konoplenko and others) between the Charmitan deposits in the east, Guzhumsay in the west.

In the general geological structure of the district, the Urtalik deposit is part of the Zarmitan gold ore zone located in the southern wing of the North Nurata anticlinorium. The zone is an integral part of the ZarafshanTurkestan structural and formation zone of the South Tien Shan Hercynian fold belt $[4,5]$. Mineralization at the Urtalik deposit is associated with northwestern, northeastern and sub-latitudinal tectonic structures.

Gold mineralization in the Urtalik deposit is localized in granitoids (P1) and to a much lesser extent in sedimentary-metamorphic rocks of the Lower Paleozoic (southern flank). It is controlled in the south of Karaulkhona by the Charmitan shear zone and is confined to the fracture structures of NE (Guzhumsay type) and NW (Charmitan type) and sub-latitudinal trending. The Urtalik site is the link between the explored Charmitan and Guzhumsay deposits, characterized by common features of the geological structure, the similarity of structural and morphological types of ores, their material composition and properties (Fig. 1).

The identified ore bodies at the Urtalik deposit are a direct continuation at the given hypsometric level of the structural positions of the ore bodies of Charmitan and Guzhumsay. 


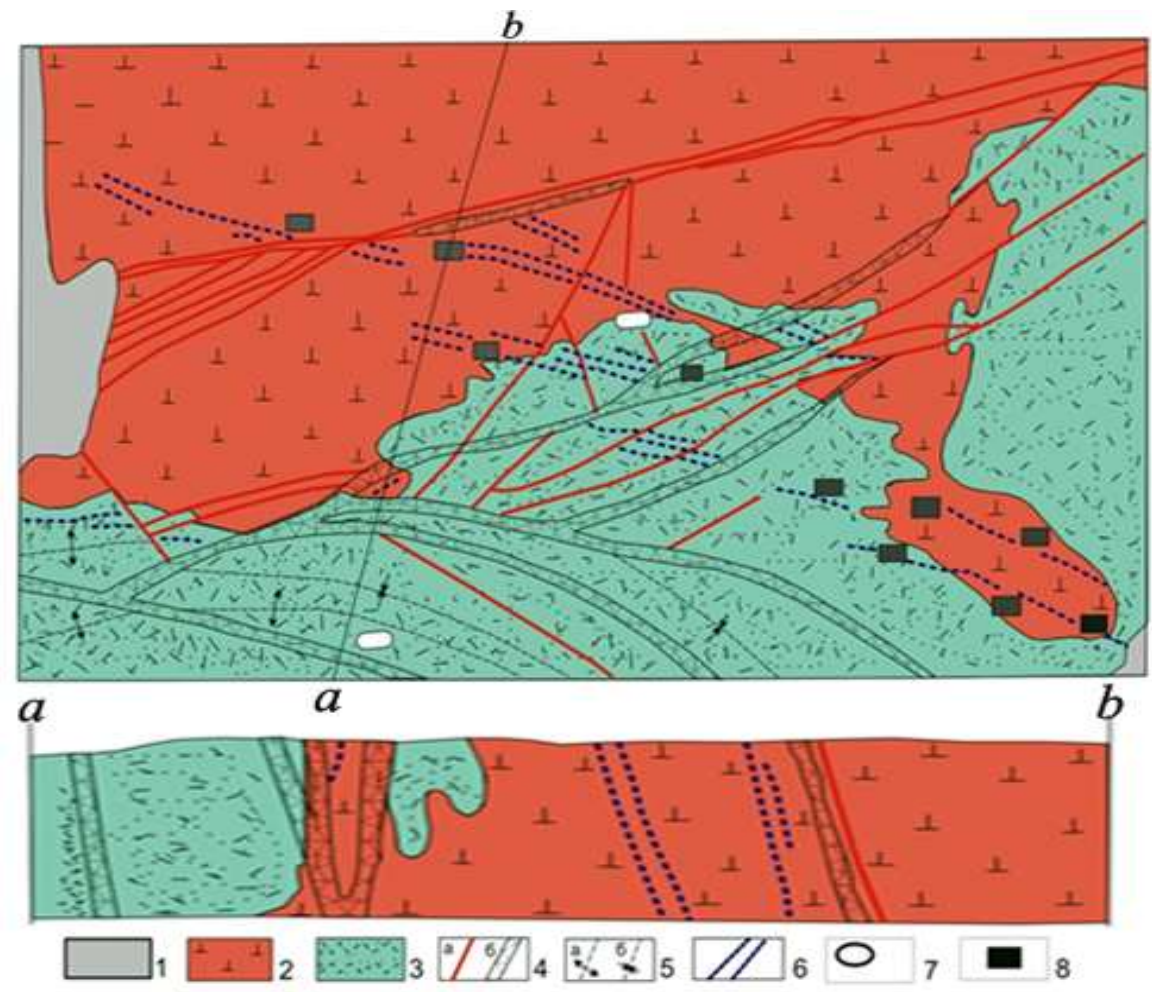

1 - Quaternary deposits; 2 - granosyenites. Koshrabad Gabbro (Essexit) - syenite-granosyenite complex $\left(\mathrm{S}_{2}\right) ; 3$ - sandstones, siltstones, schists, tuffs of medium composition; 4 - faults (a) and crushed rock zone (b); 5 - axis of the folds: a - anticlinal, b - synclinal; 6 - quartz veins ore-bearing; 7 mouth adit; 8 - mines

Fig. 1. Schematic geological map of the Charmitan field

Our main task was to study in detail the metasomatites of the deposit with their division into facies differences, to establish the mineralogical and geochemical criteria for their zonality with the elucidation of the spatial position of the identified metasomatic formations.

In the Charmitansky ore field, near-ore metasomatites are widely developed. Earlier V.A. Khorvat et al. [17-18] noted that in the ore field, the processes of albitization and kalifeldsparization have a temporal and genetic affinity, and together they make up the quartz-feldspar formation of ore ore changes controlling quartz-scheelite and quartz-gold ore formations. T.zh. Tulegenov et al. emphasized the special role of near-ore alterations in the distribution of quartz - sulfide vein ore bodies related to the berezite formation. According to I.P. Sherban, R.V. Tsoi and I.P. Ivanova et al. In the Charmitan ore field, ore-bearing bodies and brecciation and crushing zones are accompanied by gumbaites, aesites and listvenite- beresites $[6,13,19]$.

Ore-bearing rocks in the Urtalik deposit are granosyenites of the Koshrabad pluton. In the south, the field contacts the Karaulkhan- 
Charmitan shear zone and a parallel narrow strip of sub-latitudinal strike of fragments of the Jazbulak Formation (S1ln32-W1dz) composed of shales, siltstones, sandstones with lenses of limestone, tuff sandstones, tuff aleurolites and interstratum sill-like bodies of diabase porphyrites and gabbro-diabases. The sediments of the suite are creased into the isoclinic folds of the west-north-west strike, underwent regional (sericite-chlorite step of the green shale facies) metamorphism and thermal effect of the invading Koshrabad intrusion.

The most common varieties of rocks in exocontact halos are spotted, nodular andalusite schists. Closer to the contact, hornfelses of various, mainly biotite-feldspar composition are noted, in some places they are marbled and garnished.

Near-ore alterations in ore-bearing rocks are represented by feldspar-quartz metasomatites, in the intermediate zones of which berezitization (silicification, carbonatization, sericitization, pyritization) is developed. Argillizite (kaolinization) metasomatites are sometimes noted [17].

Quartz-feldspar metasomatites [13] are most contrasted in the selvages of low-sulphide quartz veins among granitoid rocks, and they are constantly associated with albite-chlorite metasomatites, forming an intermediate zone of altered rocks. The transformed granosyenites acquire pink, yellowish pink, and away from the veins become grayish and yellowish green. In hornfelses, this process is markedly weaker and is almost not accompanied by changes in the color of the rocks. The shape of the metasomatic bodies depends on the morphology of the orecontaining faults and on the thickness of the veins. Strip-shaped, space-boring rims and lenses with a thickness from the first centimeters to 1-2 $\mathrm{m}$ prevail.

The processes of berezitization and listvenitization were most pronounced at the contact of the intrusive massif and in the hornfelses. Intensively transformed rocks are distinguished by a yellowish-greenish color, a complete loss of primary structural and texture features. They are characterized by a complex shape, to some extent subordinate to discontinuous tectonics and rock contacts.

The inner zones of the column of beresite alterations and contacts with ore veins are sometimes composed of quartz-feldspar metasomatites, on which carbonate-sericite formations are superimposed. The thickness of beresitization zones does not exceed 0.5-1.om.

Argillisite changes accompany veins with increased polysulfide mineralization (sphalerite, galena) and are expressed in a noticeable increase in the proportion of hydromica and the appearance of clay minerals. Argillisitic alterations were reliably established by V. Khrenov. and V.A. Khorvat by core drill in the southern zone of the Charmitan field. Among the granosyenites altered by berezitization, accumulations of clay minerals in the form of small nests $(0.3-0.5 \mathrm{~cm})$ and veins are recorded. In some cases, there are accumulations of hydromica and kaolin, up to $20 \%$ of the rock volume. In general, the process of argillization is weak and mosaic, mainly on the flanks of the deposit, in close spatiotemporal proximity with beresite metasomatism [9-10, 17].

In the Charmitan ore field, localization of mineralization is determined by tectonic, magmatic and lithological factors. The Karaulkhan-Charmitan zone of the sublatitudinal long-lived fault belongs to the tectonic one, with a series of sub-parallel 
faults, whose cleft faults are of the west-northwest strike with a steep northern dip, are the main ore-bearing structures. The zone is accompanied by intense shalefication, coalification, brecciation and milonization of the host rocks. The named fault is the main magma-leading and ore-controlling channel of the ore field.

The gold ore geochemical specialization of the Koshrabad intrusive complex [3, 12, 15, 20] relates to the magmatic mineralization control factor, confirmed by the presence of native gold among accessory minerals and the fact that its concentrations increase in the most silicic rocks. The lithological factor is expressed in the fact that complexly distributed volcanicterrigenous deposits of the Jazbulak Formation in the exocontact zone of the Koshrabad intrusion, subject to thermal metamorphism and acquired as a result of mechanical properties (fragility and high permeability), are favorable for fragmentation and formation of cleaved fractures and the localization of vein and quartz gold vein mineralization.

Gumbaites are distinguished by a light greenish-pink color, retain the structural and textural features of the initial graniosyenites and consist of primary feldspar, quartz and partially survived by complete replacement of plagioclase phenocrysts with sericite. Metasomatic potassium feldspar crystals replace most of the plagioclase, form small monomineral aggregates or together with quartz, inheriting the porphyry appearance of the quartz-feldspar bulk of the primary rock. The recrystallized part of the initial potassium feldspar in fine-grained aggregates, autolysed from pelite. Quartz is quantitatively inferior to secondary feldspar and composes small monomineral areas of silicification in the rock. Carbonate forms small clusters of grains in the feldspar mass of the rock. Chlorite is found in rare plates. The presence in gumbaites of an insignificant amount of sericite is explained by relics of beresitization zones.

According to the authors of [13], beresites are developed mainly at deep horizons and accompany veinlet-disseminated, sulfidequartz and sulfide mineralization proper of the stockwork morphotype. The thickness of the zones of beresitization varies depending on the intensity of the tectonic development of the fracture-permeable zones from the first to several tens of meters. In places of rather active occurrence of granosyenite beresitization according to conversion intensity and mineral composition, the authors identified three types of alterations corresponding to rocks of the external, intermediate, and internal zones of the conditional metasomatic column.

The outer zone is characterized by the chloritization of the dark-colored minerals of the source rocks. Carbonate, fine hydromica flakes, and fine grains of ore material are noted in the contours of dark-colored minerals replaced by chlorite. Plagioclase is partially sericitized, and the initial quartz and potassium feldspar with traces of pelitization preserve the primary structure of granosyenites. In the intermediate zone, due to more intensive sericitization of the feldspar part, the rock acquires a light pink, greenish-pink color due to the rock-forming non-stericized feldspar. Chlorite sometimes in association with carbonate partially replaces hornblende. At the periphery of the grains, iron hydroxides (tabular phenocrysts) are separated. They are completely covered with a black opaque mass. The leading metasomatic mineral is sericite ( $\mathrm{SiO}_{2}$ - 45,71; $\mathrm{A}_{12} \mathrm{O} 3$ - 38,70; $\mathrm{FeO}$ - 1,37; $\mathrm{Na} 2 \mathrm{O}$ 0,$17 ; \mathrm{K} 2 \mathrm{O}-10,47 \%$ ), which accounts for about $30 \%$ of growths, followed by quartz, replacing 
mainly the original potassium feldspar, partially sericitized plagioclase. It forms small monomineral clusters or is associated with sericites on feldspars.

A characteristic feature of the intermediate metasomatic zone is the greater degree of its sulfidization of the vein-disseminated type. Sulfides (pyrite and arsenopyrite) are mainly concentrated in veins of various thicknesses, morphology, configurations and lengths. Most often, thin veins are filled with sulfides intermittently with alternating sulfide-free intervals, chains. Larger continuous veins have a complex internal structure with numerous xenoliths of serialized host rock. Elongated sulfide inclusions of the most bizarre configuration are also significant.

Metasomatites, corresponding in degree of conversion and mineral composition to the inner zone of alterations, have a simple quartzsericite composition with carbonate and sulfides with the predominant role of sericite, which replaced most of the feldspar component of the original rock. Carbonate is present in single grains, but in places forms small clusters. The amount of quartz increases markedly due to the development of a finegrained metasomatic difference. Primary quartz is recrystallized and in most cases indistinguishable from metasomatic. Developing in isometric precipitates, secondary quartz sometimes forms continuous clusters, replacing feldspars as well as sericite, but in general, sericite remains leading. In addition to these types of alterations, the authors noted a less widespread group of hydrothermally altered rocks in the deep horizons of the deposit, corresponding to the formation of aesites, which form thin quartzalbite bodies in beresitized granosyenites. They are like albitites or albite metasomatites, which compose zones of low thickness on the surface and upper horizons of a deposit, described by I.Kh. Khamrabaev [14-16], V.A. Khorvat [17-18], I.P. Sherban [19] and others. The main conclusion of the authors on the results of studying metasomatites of the deep horizons of the Charmitan deposit is formulated by him in the following expressions: "Thus, at the deep horizons (700-1200 $\mathrm{m}$ from the surface) of the Charmitan deposit, the same ore metasomatites of the Gumbaite and Beresite formations are not less widely developed. Which compose the upper parts of industrial ore bodies. Therefore, the close spatial and age-related relationship of gold ore mineralization with gumbeites and berezites allows them to be used as search and evaluation criteria for the industrial potential of the deep horizons of the deposit and its flanks". Unfortunately, such a conclusion is too generalized and until the spatial relationship and distribution of the identified metasomatic formations along the vertical and lateral, tied to a specific geological situation, are determined, they have no greater predictive value. Information similar to the above about metasomatic formations of the Urtalik deposit, which we reviewed literary sources, was not found.

Our observations on the southeastern flank of the Charmitan deposit showed a widespread development of rare-earth mineralization due to metasomatites of the beresite- listvenite, hornfels and argillizite formations of ore ore changes reaching industrial values in terms of ytterbium content [8].

\section{RESULTS AND DISCUSSIONS}

An indicator mineral showing changes in the acidity and alkalinity of metasomatic solutions is, along with barite anhydrite (BaSO4), which is a product of sulfuric acid metasomatism. The role of anhydridization and baritization in the distribution of copper-molybdenum, 
polymetallic and gold ores is studied in detail on the example of the Almalyk ore district by S.T. Badalov and A.Kh. Turesebekov [2].

The ore bodies of the Urtalik deposit are oriented in the NW-NE and NW directions and are traced along strike along a distance from 80 to $1600 \mathrm{~m}$. Their fall is steep on the NNW (65-850), their thicknesses are small - from 0.20 to $1.70 \mathrm{~m}$, in blow - up to $9.0 \mathrm{~m}$. Ore-bearing rocks at the deposit are granosyenites of the Koshrabad massif. Mineralization is confined to cleft fracture systems икфтсріng the Central Fault.

Samples of ore-bearing rocks and ores of the Urtalik deposit of the Zarmitan ore-bearing zone, taken from pits No. 10, No. 14, were studied and selected among them the most informative for studies on mass spectrometric, spectrographic aurometric and spectral analyzes.

In pit No. 10, carbonaceous shales with sulfide minerals, granodiorites with streaks of quartz, quartzites, schistose layered hornfelses and granosyenites are found. Almost all rocks are metamorphosed, argillized, limonitized. Carbonaceous shales are silicified and sulfitized. Quartz veins are impregnated with pyrites, arsenopyrites, chalcopyrites and hematites.

In pit No. 14, slightly listvenitized, silicified granodiorites, porphyry diorites, carbonated, iron-bearing full-crystalline granosyenites and quartz veins with sulfide minerals from $5 \mathrm{~cm}$ to $1.2 \mathrm{~m}$ thick are found. Quartz veins are impregnated with pyrites, arsenopyrites, chalmatopyrites and others. rocks from pit No. 14, pits from pit No. 10 are much rich in sulfide minerals, but shales were much less common.
The results of mass spectrometric determination, the content of impurity elements in the selected samples were recalculated to clarke concentrations in the earth's crust (according to A.P. Vinogradov, 1962), diagrams were constructed on their basis, which are described below and made brief geochemical conclusions (Table 1,2).

Based on the general picture of the distribution of impurity elements in ore-bearing rocks and ores of the Urtalik deposit relative to their clarks in the earth's crust, it can be noted that in all samples the contents of the following elements are high: lithium, cesium, iron, bromine, scandium, yttrium, rhenium, europium, and terbium, uranium, zinc, arsenic, selenium, tellurium, tungsten, bismuth, antimony, ytterbium, molybdenum; elements of the metal group, elements of metalloid and metallogenic and noble elements (Fig. 2, 3, 4). Significantly higher levels of arsenic, selenium and tellurium prove that the rock contains an increased gold content. Values of bismuth, tungsten and silver are also hundreds of times higher than clarke.

Selected samples have markedly increased contents of titanium, iron, which are part of ilmenite (FeTiO3). Ilmenite is often found in alkaline rocks in the form of phenocrysts. Higher clarke values for nickel, cobalt and chromium. In Urt-72 sample, increased manganese concentrations (6.9 times). 
The American Journal of Social Science and Education Innovations (ISSN - 2689-100x)

Published: September 10, 2020 | Pages: 79-100

Doi: https://doi.org/10.37547/tajssei/Volumeo2Issue09-12

2020: $5 \cdot 525$

The results of mass spectrometric analysis of rocks of the Urtalik deposit of the Charmitansky ore

field, the distribution of impurity elements

in $(\mathrm{ppm}, \mathrm{mkg} / \mathrm{g}, \mathrm{g} / \mathrm{t})$

\begin{tabular}{|c|c|c|c|c|c|c|c|c|c|c|}
\hline \multicolumn{11}{|c|}{ Source data divided by groups } \\
\hline Elements & Urt-72 & Urt-75 & Urt-213 & Urt-228 & Urt-237 & Urt-238 & Urt-248 & Urt-256 & Urt-258 & Urt-259 \\
\hline \multicolumn{11}{|c|}{ Rock elements } \\
\hline Al & 32000 & 19000 & 19086 & 21227 & 54280 & 36635 & 29006 & 40771 & 36946 & 35291 \\
\hline Mg & 1500 & 2100 & 758 & 1673 & 1559 & 1565 & 5932 & 2377 & 4619 & 2929 \\
\hline $\mathrm{Ca}$ & 9900 & 11000 & 5633 & 132708 & 1079 & 431 & 8393 & 60390 & 17012 & 18600 \\
\hline $\mathrm{Na}$ & 10000 & 15000 & 4078 & 2552 & 4283 & 3817 & 4576 & 11409 & 25454 & 26189 \\
\hline K & 15000 & 29000 & 7553 & 7611 & 28944 & 13980 & 16992 & 12694 & 26554 & 23487 \\
\hline Li & 33 & 76 & 18,04 & 16,76 & 22,64 & 19,94 & 29,82 & 43,54 & 62,38 & 71,57 \\
\hline $\mathrm{Be}$ & 1,10 & 2,50 & 0,64 & 0,70 & 0,84 & 0,63 & 1,50 & 1,80 & 2,06 & 3,49 \\
\hline $\mathbf{R b}$ & 77 & 120 & 9,61 & 12,06 & 141,08 & 32,99 & 24,97 & 24,46 & 192,50 & 122,04 \\
\hline Sr & 87 & 110 & 19,19 & 124,3 & 26,78 & 20,82 & 22,68 & 24,56 & 81,64 & 159,80 \\
\hline Cs & 1,70 & 4,10 & 0,99 & 1,60 & 4,96 & 4,61 & 4,90 & 4,29 & 5,55 & 5,12 \\
\hline $\mathrm{Ba}$ & 280 & 1000 & 51,19 & 59,15 & 53,79 & 51,20 & 37,56 & 78,92 & 952,75 & 732,52 \\
\hline \multicolumn{11}{|c|}{ Elements of magmatic emanations } \\
\hline B & 19 & 20 & 19,9 & 20,9 & 27,2 & 24,7 & 24,4 & 22,4 & 21,6 & 23,1 \\
\hline $\mathbf{P}$ & 300 & 520 & 157,4 & 130,8 & 386,9 & 277,8 & 227,9 & 342,3 & 624,3 & 568,9 \\
\hline \multicolumn{11}{|c|}{ Elements of the iron group } \\
\hline $\mathrm{Ti}$ & 820 & 1400 & 167,4 & 159,3 & 333,8 & 337 & 221,1 & 1093,6 & 3033,3 & 2001 \\
\hline $\mathbf{V}$ & 13 & 15 & 1,2 & 1,3 & 2,3 & 2,3 & 1,6 & 3,5 & 29,9 & 6,2 \\
\hline $\mathrm{Cr}$ & 31 & 42 & 17,4 & 14,1 & 14 & 16,4 & 17,2 & 14,2 & 37,6 & 19 \\
\hline $\mathrm{Mn}$ & 6900 & 270 & 169,3 & 1308,3 & 28,3 & 29,6 & 260,8 & 699 & 427,6 & 186,3 \\
\hline $\mathrm{Fe}$ & 73000 & 32000 & 58878 & 78180 & 185936 & 118027,8 & 153240,3 & 68479,1 & 34233,6 & 28847,9 \\
\hline Co & 2,6 & 5,6 & 10,2 & 12,3 & 52,4 & 7,3 & 14,7 & 7,3 & 7,8 & 4,8 \\
\hline
\end{tabular}


The American Journal of Social Science and Education Innovations (ISSN - 2689-100x)

Published: September 10, 2020 | Pages: 79-100

Doi: https://doi.org/10.37547/tajssei/Volumeo2Issue09-12

\begin{tabular}{|c|c|c|c|c|c|c|c|c|c|c|}
\hline $\mathrm{Ni}$ & 40 & 63 & 6,6 & 5 & 4,6 & 3,1 & 7,9 & 3,6 & 14,1 & 5,6 \\
\hline \multicolumn{11}{|c|}{ Group of rare and rare earth elements } \\
\hline Sc & 1,90 & 2,20 & 1,35 & 2,84 & 1,59 & 0,92 & 1,86 & 2,98 & 4,09 & 3,68 \\
\hline $\mathbf{Y}$ & 12 & 18 & 5,62 & 36,32 & 8,15 & 4,92 & 11,30 & 20,34 & 29,48 & 28,34 \\
\hline $\mathrm{Zr}$ & 17 & 21 & 10,14 & 11,16 & 37,54 & 29,59 & 16,77 & 25,19 & 55,09 & 44,24 \\
\hline Hf & 0,82 & 1 & 0,27 & 0,30 & 1,13 & 0,99 & 0,47 & 0,71 & 1,54 & 1,30 \\
\hline Nb & 6,40 & 10 & 2,43 & 1,84 & 4,85 & 4,88 & 3,06 & 7,63 & 17,17 & 13,04 \\
\hline $\mathrm{Ta}$ & 0,49 & 0,75 & 0,14 & 0,15 & 0,41 & 0,40 & 0,23 & 0,52 & 1,25 & 0,93 \\
\hline Mo & 2,40 & 2,90 & 9,73 & 9,93 & 9,18 & 7,41 & 9,62 & 12,03 & 13,54 & 10,09 \\
\hline W & 34 & 200 & 5733,7 & 1770,4 & 7,93 & 4,24 & 653,37 & 669,06 & 15,55 & 28,35 \\
\hline $\mathbf{R e}$ & 0,001 & 0,004 & 0,126 & 0,032 & 0,001 & 0,001 & 0,001 & 0,13 & 0,00 & 0,09 \\
\hline La & 10 & 23 & 22,56 & 17,50 & 6,21 & 8,31 & 15,31 & 25,01 & 36,38 & 27,16 \\
\hline $\mathrm{Ce}$ & 31 & 36 & 25,37 & 12,68 & 8,90 & 10,82 & 16,99 & 52,37 & 69,15 & 61,67 \\
\hline $\mathrm{Pr}$ & 3,60 & 5,40 & 3,89 & 4,33 & 1,97 & 2,14 & 3,14 & 5,18 & 8,12 & 6,93 \\
\hline Nd & 13 & 20 & 12,87 & 17,10 & 7,86 & 9,30 & 11,40 & 20,61 & 29,95 & 28,13 \\
\hline Sm & 2,70 & 4,30 & 2,25 & 4,25 & 1,64 & 1,74 & 2,17 & 3,88 & 5,96 & 5,74 \\
\hline Eu & 0,54 & 1 & 0,31 & 1,28 & 0,36 & 0,38 & 0,42 & 0,72 & 1,46 & 1,19 \\
\hline Gd & 2,50 & 4,00 & 1,75 & 4,77 & 1,79 & 1,54 & 2,19 & 3,35 & 5,49 & 4,91 \\
\hline Tb & 0,37 & 0,60 & 0,24 & 0,92 & 0,26 & 0,21 & 0,32 & 0,53 & 0,96 & 0,87 \\
\hline Dy & 2,30 & 3,60 & 1,29 & 6,30 & 1,56 & 1,04 & 2,02 & 3,15 & 5,54 & 5,18 \\
\hline Ho & 0,43 & 0,69 & 0,21 & 1,14 & 0,31 & 0,20 & 0,35 & 0,63 & 1,12 & 1,06 \\
\hline Er & 1,20 & 1,90 & 0,51 & 2,75 & 0,78 & 0,49 & 1,18 & 1,67 & 2,77 & 2,83 \\
\hline Tm & 0,16 & 0,27 & 0,09 & 0,44 & 0,12 & 0,08 & 0,14 & 0,23 & 0,35 & 0,36 \\
\hline $\mathrm{Yb}$ & 1,10 & 1,80 & 0,49 & 2,46 & 0,87 & 0,51 & 1,10 & 1,43 & 2,49 & 2,68 \\
\hline Lu & 0,15 & 0,25 & 0,08 & 0,32 & 0,11 & 0,09 & 0,13 & 0,19 & 0,32 & 0,36 \\
\hline \multicolumn{11}{|c|}{ Group of radioactive elements } \\
\hline Th & 5,80 & 8,70 & 6,12 & 3,84 & 5,05 & 4,26 & 4,04 & 5,82 & 13,78 & 12,11 \\
\hline
\end{tabular}


The American Journal of Social Science and Education Innovations (ISSN - 2689-100x)

Published: September 10, 2020 | Pages: 79-100

Doi: https://doi.org/10.37547/tajssei/Volume02Issueo9-12

2020: $5 \cdot 525$

\begin{tabular}{|c|c|c|c|c|c|c|c|c|c|c|}
\hline $\mathbf{U}$ & 2,80 & 4,00 & 1,21 & 4,47 & 3,95 & 2,42 & 1,89 & 3,64 & 1,32 & 1,77 \\
\hline \multicolumn{11}{|c|}{ Elements of a group of metal ores } \\
\hline $\mathrm{Cu}$ & 48 & 11 & 18,26 & 4 & 3,10 & 2,38 & 10,24 & 5,06 & 13,14 & 3,05 \\
\hline Zn & 220000 & 120 & 263,86 & 1891,6 & 5695 & 82,6 & 3481,5 & 30077,4 & 102,09 & 360,5 \\
\hline Ga & 7,70 & 18 & 4,692 & 4,557 & 13,834 & 12,450 & 8,01 & 9,596 & 20,799 & 20,396 \\
\hline Cd & 2500 & 1,40 & 3,693 & 3,970 & 15,421 & 0,632 & 12,65 & 130,253 & 0,579 & 4,708 \\
\hline In & 61 & 0,065 & 0,160 & 0,128 & 0,64 & 0,052 & 0,326 & 3,007 & 0,051 & 0,127 \\
\hline Sn & 11 & 5,70 & 2,55 & 1,69 & 3,47 & 3,50 & 8,45 & 11,37 & 4,67 & 10,27 \\
\hline TI & 1,60 & 0,590 & 0,198 & 2220,664 & 1,315 & 0,95 & 14,59 & 1,819 & 1,268 & 0,985 \\
\hline $\mathbf{P b}$ & 110000 & 2900 & 13000 & 12975 & 355,34 & 310,7 & 107532 & 25510,3 & 30,70 & 17067,9 \\
\hline \multicolumn{11}{|c|}{ Group of metalloid and metallogenic elements } \\
\hline Bi & 130 & 8 & 5839,2 & 238,31 & 2,63 & 0,98 & 4575,7 & 322,50 & 0,80 & 9,78 \\
\hline As & 10000 & 8500 & 6057,5 & 56610 & 163842 & 157796 & 41281 & 61282,0 & 179,90 & 7335,2 \\
\hline Se & 63 & 8,80 & 13,79 & 23,23 & 18,56 & 11,95 & 83,17 & 18,58 & 2,38 & 7,91 \\
\hline Sb & 370 & 18 & 3221,9 & 50,36 & 924,65 & 542,87 & 72,19 & 417,48 & 7,54 & 24,38 \\
\hline Te & 3,20 & 3,70 & 317,98 & 11,21 & 0,73 & 0,06 & 35,67 & 11,99 & 0,15 & 0,33 \\
\hline \multicolumn{11}{|c|}{ Elements of the noble metal group } \\
\hline Pt & 0,0028 & 0,0036 & 0,001 & 0,001 & 0,001 & 0,001 & 0,001 & 0,001 & 0,007 & 0,007 \\
\hline $\mathrm{Au}$ & 92,92 & 0,715 & 58,67 & 0,43 & 73,27 & 4,80 & 14,05 & 82,78 & 6,62 & 7,27 \\
\hline $\mathrm{Ag}$ & 450 & 14 & 1635,6 & 52,92 & 37,07 & 5,89 & 1796,12 & 1190,73 & 1,673 & 43,30 \\
\hline
\end{tabular}

Table 2

The ratio of impurity elements in the rocks of the Urtalik deposit of the Charmitan ore field to clarks in the earth's crust (according to A.P. Vinogradov)

\begin{tabular}{|c|c|c|c|c|c|c|c|c|c|c|}
\hline \multicolumn{11}{|c|}{ Groups by clarks in the Earth's Crust } \\
\hline Elements & Urt-72 & Urt-75 & Urt-213 & Urt-228 & Urt-237 & Urt-238 & Urt-248 & Urt-256 & Urt-258 & Urt-259 \\
\hline \multicolumn{11}{|c|}{ Rock elements } \\
\hline
\end{tabular}


The American Journal of Social Science and Education Innovations (ISSN - 2689-100x)

Published: September 10, 2020 | Pages: 79-100

Doi: https://doi.org/10.37547/tajssei/Volumeo2Issue09-12

\begin{tabular}{|c|c|c|c|c|c|c|c|c|c|c|}
\hline Al & 0,40 & 0,24 & 0,24 & 0,3 & 0,67 & 0,46 & 0,36 & 0,51 & 0,46 & 0,44 \\
\hline $\mathrm{Mg}$ & 0,08 & 0,11 & 0,04 & 0,1 & 0,08 & 0,08 & 0,32 & 0,13 & 0,25 & 0,16 \\
\hline $\mathrm{Ca}$ & 0,33 & 0,37 & 0,19 & 4,5 & 0,04 & 0,01 & 0,28 & 2,04 & 0,57 & 0,63 \\
\hline $\mathrm{Na}$ & 0,40 & 0,60 & 0,16 & 0,1 & 0,17 & 0,15 & 0,18 & 0,46 & 1,02 & 1,05 \\
\hline K & 0,60 & 1,16 & 0,30 & 0,3 & 1,16 & 0,56 & 0,68 & 0,51 & 1,06 & 0,94 \\
\hline Li & 1,03 & 2,38 & 0,56 & 0,5 & 0,71 & 0,62 & 0,93 & 1,36 & 1,95 & 2,24 \\
\hline $\mathrm{Be}$ & 0,29 & 0,66 & 0,17 & 0,2 & 0,22 & 0,17 & 0,39 & 0,47 & 0,54 & 0,92 \\
\hline $\mathbf{R b}$ & 0,51 & 0,80 & 0,06 & 0,1 & 0,94 & 0,22 & 0,17 & 0,16 & 1,28 & 0,81 \\
\hline $\mathrm{Sr}$ & 0,26 & 0,32 & 0,06 & 0,4 & 0,08 & 0,06 & 0,07 & 0,07 & 0,24 & 0,47 \\
\hline Cs & 0,46 & 1,11 & 0,27 & 0,4 & 1,34 & 1,25 & 1,33 & 1,16 & 1,50 & 1,38 \\
\hline $\mathrm{Ba}$ & 0,43 & 1,54 & 0,08 & 0,1 & 0,08 & 0,08 & 0,06 & 0,12 & 1,47 & 1,13 \\
\hline \multicolumn{11}{|c|}{ Elements of magmatic emanations } \\
\hline B & 1,58 & 1,67 & 1,66 & 1,74 & 2,27 & 2,06 & 2,04 & 1,87 & 1,80 & 1,93 \\
\hline $\mathbf{P}$ & 0,32 & 0,56 & 0,17 & 0,14 & 0,42 & 0,30 & 0,25 & 0,37 & 0,67 & 0,61 \\
\hline \multicolumn{11}{|c|}{ Elements of the iron group } \\
\hline $\mathrm{Ti}$ & 0,18 & 0,31 & 0,04 & 0,04 & 0,07 & 0,07 & 0,05 & 0,24 & 0,67 & 0,44 \\
\hline $\mathbf{v}$ & 0,14 & 0,17 & 0,01 & 0,01 & 0,03 & 0,03 & 0,02 & 0,04 & 0,33 & 0,07 \\
\hline $\mathrm{Cr}$ & 0,37 & 0,51 & 0,21 & 0,17 & 0,17 & 0,20 & 0,21 & 0,17 & 0,45 & 0,23 \\
\hline $\mathrm{Mn}$ & 6,90 & 0,27 & 0,17 & 1,31 & 0,03 & 0,03 & 0,26 & 0,70 & 0,43 & 0,19 \\
\hline $\mathrm{Fe}$ & 1,57 & 0,69 & 1,27 & 1,68 & 4,00 & 2,54 & 3,30 & 1,47 & 0,74 & 0,62 \\
\hline Co & 0,14 & 0,31 & 0,57 & 0,68 & 2,91 & 0,40 & 0,81 & 0,41 & 0,43 & 0,27 \\
\hline $\mathrm{Ni}$ & 0,69 & 1,09 & 0,11 & 0,09 & 0,08 & 0,05 & 0,14 & 0,06 & 0,24 & 0,10 \\
\hline \multicolumn{11}{|c|}{ Group of rare and rare earth elements } \\
\hline Sc & 0,76 & 0,88 & 0,54 & 1,14 & 0,64 & 0,37 & 0,74 & 1,19 & 1,64 & 1,47 \\
\hline $\mathrm{Y}$ & 0,60 & 0,90 & 0,28 & 1,82 & 0,41 & 0,25 & 0,57 & 1,02 & 1,47 & 1,42 \\
\hline $\mathrm{Zr}$ & 0,10 & 0,12 & 0,06 & 0,07 & 0,22 & 0,17 & 0,10 & 0,15 & 0,32 & 0,26 \\
\hline $\mathrm{Hf}$ & 0,82 & 1,00 & 0,27 & 0,30 & 1,13 & 0,99 & 0,47 & 0,71 & 1,54 & 1,30 \\
\hline
\end{tabular}


The American Journal of Social Science and Education Innovations (ISSN - 2689-100x)

Published: September 10, 2020 | Pages: 79-100

Doi: https://doi.org/10.37547/tajssei/Volumeo2Issue09-12

\begin{tabular}{|c|c|c|c|c|c|c|c|c|c|c|}
\hline $\mathbf{N b}$ & 0,32 & 0,50 & 0,12 & 0,09 & 0,24 & 0,24 & 0,15 & 0,38 & 0,86 & 0,65 \\
\hline Ta & 0,20 & 0,30 & 0,06 & 0,06 & 0,16 & 0,16 & 0,09 & 0,21 & 0,50 & 0,37 \\
\hline Mo & 2,18 & 2,64 & 8,84 & 9,03 & 8,35 & 6,73 & 8,75 & 10,93 & 12,31 & 9,17 \\
\hline $\mathbf{w}$ & 26,15 & 153,85 & 4410,56 & 1361,85 & 6,10 & 3,27 & 502,59 & 514,66 & 11,96 & 21,81 \\
\hline $\mathbf{R e}$ & 1,43 & 5,00 & 179,98 & 45,00 & 1,43 & 1,43 & 1,43 & 180,00 & 1,43 & 128,57 \\
\hline La & 0,34 & 0,79 & 0,78 & 0,60 & 0,21 & 0,29 & 0,53 & 0,86 & 1,25 & 0,94 \\
\hline $\mathrm{Ce}$ & 0,44 & 0,51 & 0,36 & 0,18 & 0,13 & 0,15 & 0,24 & 0,75 & 0,99 & 0,88 \\
\hline $\mathrm{Pr}$ & 0,40 & 0,60 & 0,43 & 0,48 & 0,22 & 0,24 & 0,35 & 0,58 & 0,90 & 0,77 \\
\hline Nd & 0,04 & 0,05 & 0,03 & 0,05 & 0,02 & 0,03 & 0,03 & 0,06 & 0,08 & 0,08 \\
\hline Sm & 0,34 & 0,54 & 0,28 & 0,53 & 0,20 & 0,22 & 0,27 & 0,48 & 0,74 & 0,72 \\
\hline Eu & 0,42 & 0,77 & 0,24 & 0,98 & 0,28 & 0,29 & 0,32 & 0,56 & 1,12 & 0,92 \\
\hline Gd & 0,31 & 0,50 & 0,22 & 0,60 & 0,22 & 0,19 & 0,27 & 0,42 & 0,69 & 0,61 \\
\hline Tb & 0,09 & 0,14 & 0,06 & 0,21 & 0,06 & 0,05 & 0,07 & 0,12 & 0,22 & 0,20 \\
\hline Dy & 0,46 & 0,72 & 0,26 & 1,26 & 0,31 & 0,21 & 0,40 & 0,63 & 1,11 & 1,04 \\
\hline Ho & 0,25 & 0,41 & 0,13 & 0,67 & 0,18 & 0,12 & 0,21 & 0,37 & 0,66 & 0,62 \\
\hline $\mathrm{Er}$ & 0,36 & 0,58 & 0,15 & 0,83 & 0,24 & 0,15 & 0,36 & 0,51 & 0,84 & 0,86 \\
\hline $\mathrm{Tm}$ & 0,59 & 1,00 & 0,35 & 1,61 & 0,43 & 0,31 & 0,53 & 0,85 & 1,29 & 1,32 \\
\hline$\overline{Y b}$ & 3,33 & 5,45 & 1,47 & 7,46 & 2,63 & 1,54 & 3,33 & 4,32 & 7,55 & 8,12 \\
\hline Lu & 0,19 & 0,31 & 0,10 & 0,40 & 0,13 & 0,11 & 0,16 & 0,24 & 0,40 & 0,45 \\
\hline \multicolumn{11}{|c|}{ Group of radioactive elements } \\
\hline Th & 0,45 & 0,67 & 0,47 & 0,30 & 0,39 & 0,33 & 0,31 & 0,45 & 1,06 & 0,93 \\
\hline U & 1,04 & 1,48 & 0,45 & 1,66 & 1,46 & 0,89 & 0,70 & 1,35 & 0,49 & 0,65 \\
\hline \multicolumn{11}{|c|}{ Elements of a group of metal ores } \\
\hline $\mathrm{Cu}$ & 1,02 & 0,23 & 0,39 & 0,09 & 0,07 & 0,05 & 0,22 & 0,11 & 0,28 & 0,06 \\
\hline Zn & 2650,60 & 1,45 & 3,18 & 22,79 & 68,62 & 0,99 & 41,95 & 362,38 & 1,23 & 4,34 \\
\hline Ga & 0,41 & 0,95 & 0,25 & 0,24 & 0,73 & 0,66 & 0,42 & 0,51 & 1,09 & 1,07 \\
\hline $\mathrm{Cd}$ & 19230,77 & 10,77 & 28,41 & 30,54 & 118,62 & 4,86 & 97,29 & 1001,95 & 4,45 & 36,21 \\
\hline
\end{tabular}


The American Journal of Social Science and Education Innovations (ISSN - 2689-100x)

Published: September 10, 2020 | Pages: 79-100

Doi: https://doi.org/10.37547/tajssei/Volumeo2Issue09-12

\begin{tabular}{|c|c|c|c|c|c|c|c|c|c|c|}
\hline In & 244,00 & 0,26 & 0,64 & 0,51 & 2,56 & 0,21 & 1,30 & 12,03 & 0,21 & 0,51 \\
\hline Sn & 4,40 & 2,28 & 1,02 & 0,68 & 1,39 & 1,40 & 3,38 & 4,55 & 1,87 & 4,11 \\
\hline TI & 1,60 & 0,59 & 0,20 & 0,66 & 1,31 & 0,95 & 14,59 & 1,82 & 1,27 & 0,99 \\
\hline $\mathbf{P b}$ & 6875,00 & 181,25 & 812,53 & 810,95 & 22,21 & 19,42 & 6720,79 & 1594,40 & 1,92 & 1066,74 \\
\hline \multicolumn{11}{|c|}{ Group of metalloid and metallogenic elements } \\
\hline $\mathrm{Bi}$ & 5882,4 & 5000,00 & 3563,27 & 33300,20 & 96377,70 & 92821,48 & 24283,48 & 36048,24 & 105,82 & 4314,84 \\
\hline As & 1260,00 & 176,00 & 275,80 & 464,65 & 371,28 & 238,93 & 1663,41 & 371,57 & 47,69 & 158,20 \\
\hline Se & 740,00 & 36,00 & 6443,80 & 100,71 & 1849,31 & 1085,73 & 144,38 & 834,97 & 15,09 & 48,75 \\
\hline Sb & 3200 & 3700 & 317983,2 & 11206,87 & 731,25 & 56,25 & 35667,74 & 11988,63 & 150 & 330,01 \\
\hline Te & 14444,44 & 888,89 & 648809 & 26479,19 & 292,38 & 108,99 & $\begin{array}{c}508416,8 \\
9\end{array}$ & 35833,46 & 89,37 & 1086,47 \\
\hline \multicolumn{11}{|c|}{ Elements of the noble metal group } \\
\hline Pt & 0,560 & 0,72 & 0,20 & 0,20 & 0,20 & 0,20 & 0,20 & 0,20 & 1,54 & 1,54 \\
\hline $\mathrm{Au}$ & 21609,44 & 166,27 & 13645,28 & 100,80 & 17040,35 & 1118,34 & 3267,60 & 19251,93 & 1540,73 & 1692,95 \\
\hline $\mathrm{Ag}$ & 6428,57 & 200 & 23366,36 & 756,06 & 529,56 & 84,10 & 25657,58 & 17010,40 & 23,903 & 618,56 \\
\hline
\end{tabular}

Note. Urt-72-granosyenite; Urt-75-granosyenite; Urt-213-sulfidized granosyenite; Urt-228 is a leucocratic, slightly beresitized granosyenite; Urt-237-contact of granite with solid ore (galena, sphalerite); Urt-238-potassium feldspar granosyenite intersects with ore (galenite) residential thickness of $1.5 \mathrm{~cm}$; Urt-248 Albitized, highly sulfidized granite; Urt-256-
Albitized Granite; Urt-258-potassium feldspar porphyry granite; Urt-259-porphyry granite interspersed with pyrite and streaked with arsenopyrite. Analyzes performed by V.A. Banov in the State Enterprise "Central Laboratory" of the State Committee for Geology of the Republic of Uzbekistan on an ICP-MS 7500 Series Agilent Technologies mass spectrometer (Japan). 


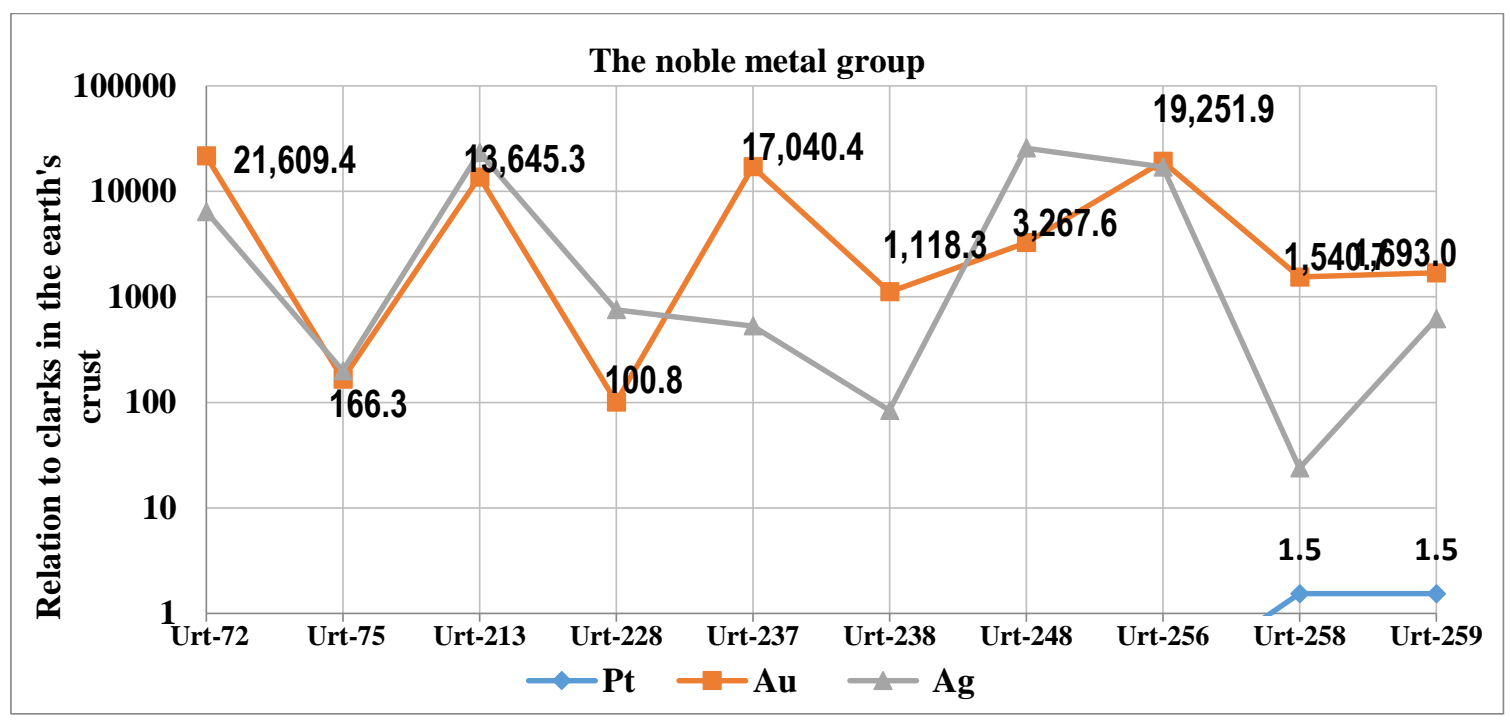

Fig. 2. Diagram of the ratio of noble metals to clarke groups in the earth's crust.

All samples are rich in scandium, yttrium, cerium and other elements belonging to the cerium (light) group of rare-earth elements (Fig. 3). Significantly high yttrium content in Urt-228, 256, 258 and 259 samples (up to 2 times). Yttrium rare earths with the main ore mineral xenotime are less common. This is a consequence of the general pattern of the distribution of rare earths in the earth's crust, where cerium rare earths always prevail over yttrium. Nevertheless, yttrium earths are developed in tangible concentrations at the Charmitan ore field. Here we find complex cerium-yttrium earths represented by zircons with metamict inclusions of rare-earth elements in the form of malacones or zirtolites.

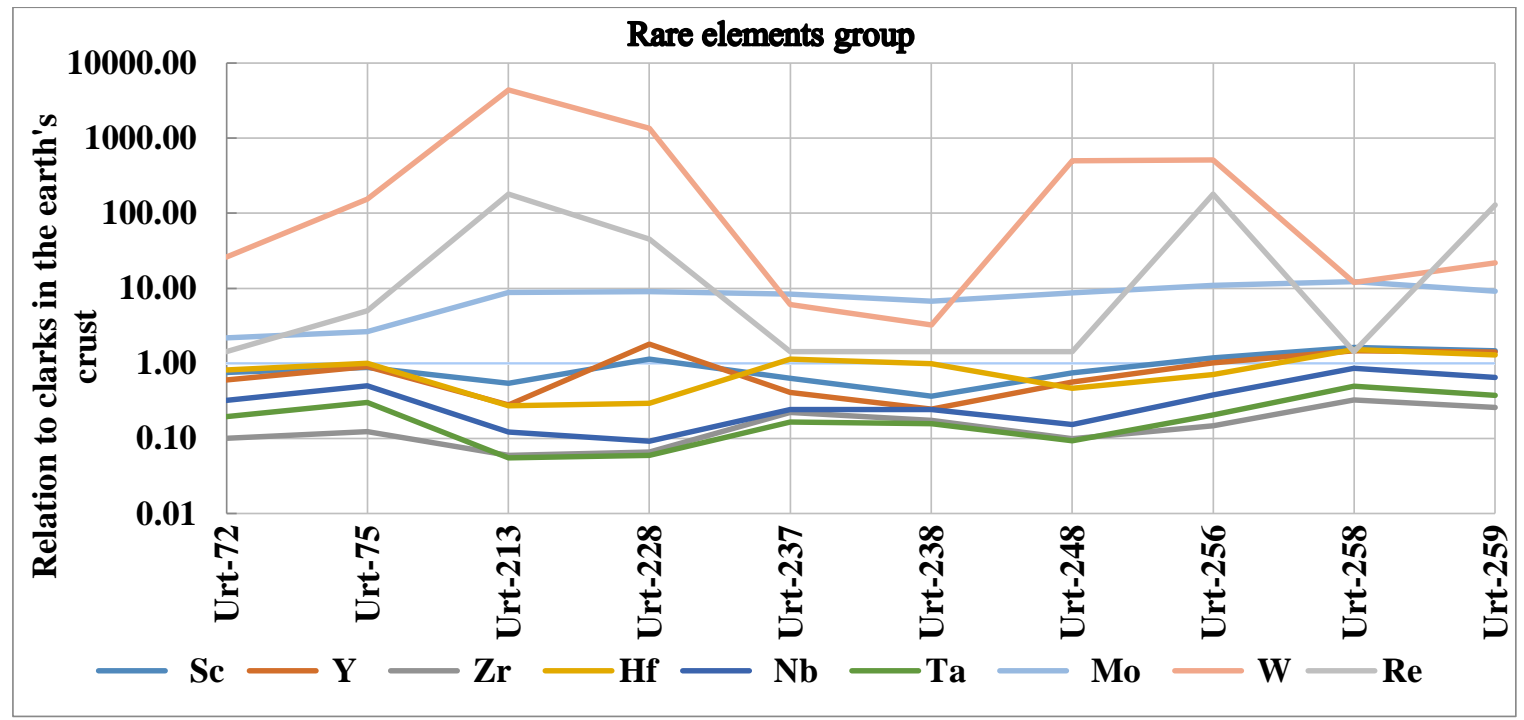

Fig. 3. The diagram of the ratio of the group of rare metals to clarks in the earth's crust. 
The American Journal of Social Science and Education Innovations (ISSN - 2689-100x)

Published: September 10, 2020 | Pages: 79-100

Doi: https://doi.org/10.37547/tajssei/Volumeo2Issue09-12

An abnormally high content of elements of the group of metal ores (Fig. 4): lead (up to 6875 times), cadmium (up to 19231 times), zinc (up to 2650 times), indium (up to 244 times), thallium (up to 15 times), tin ( up to 4.5 times) in many samples. An elevated clark content of elements of the metalloid and metallogenic group is observed along the section (Fig. 5): bismuth, arsenic, selenium, antimony, and tellurium. We consider this the result of the paragenetic connection of the named minerals with the traditional gold-rare-metal-rare-earth industrial type that is characteristic of the entire Charmitan ore field unique to the South Tien Shan.

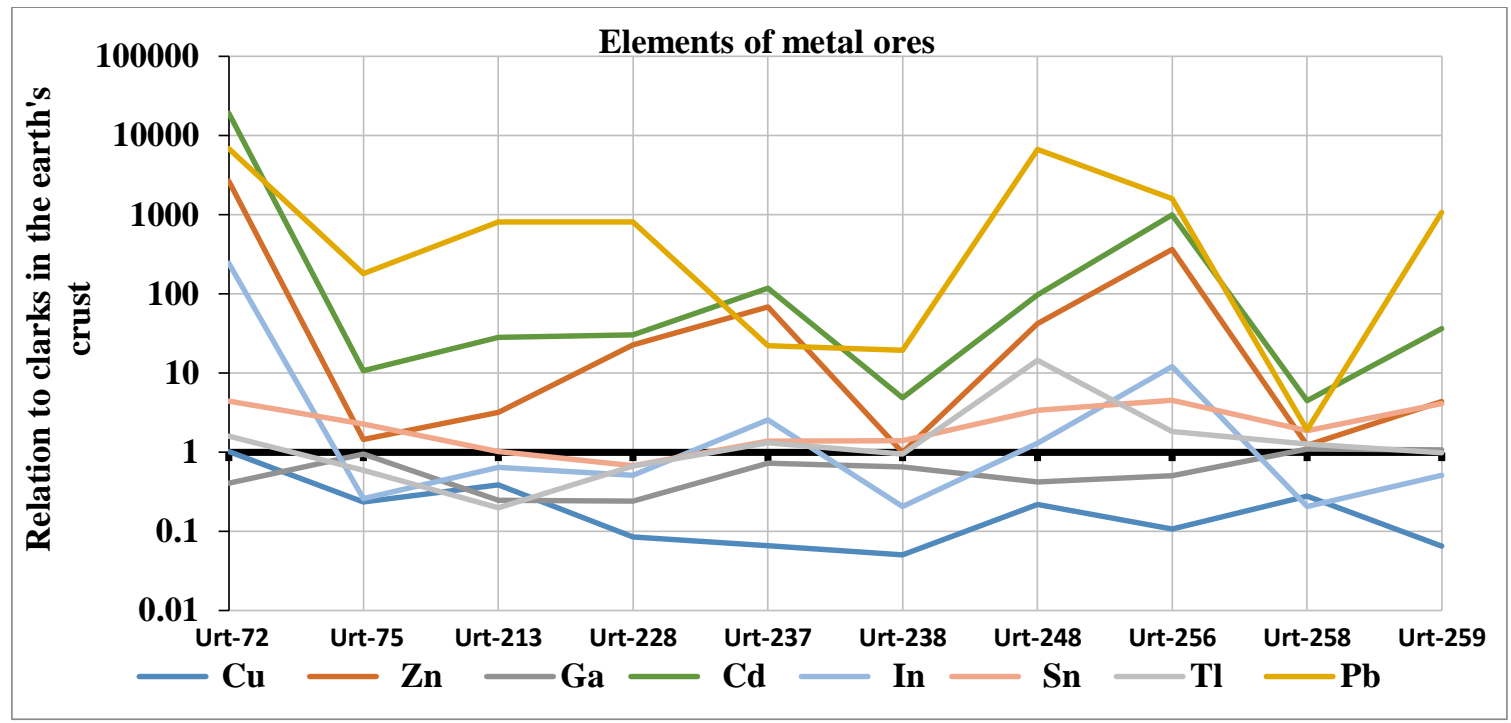

Fig. 4. The diagram of the ratio of the group of metal ores to clarks in the earth's crust.

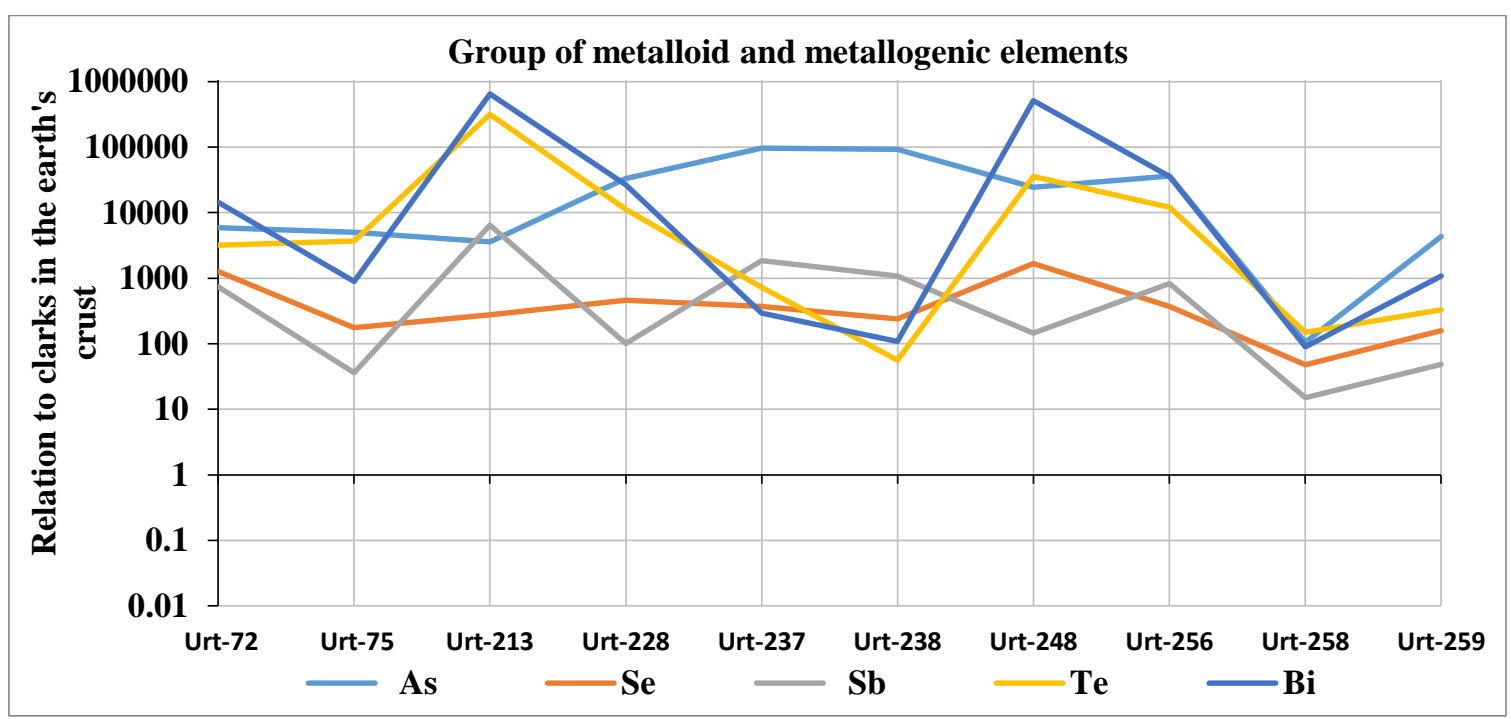

Fig. 5. The diagram of the ratio of the group of metalloid and metallogenic to clarks in the earth's crust. 
In the rocks and ores of the Urtalik deposit, W values exceeding the clarke concentration are observed (up to 4,410 times) (Fig. 3). Most likely, the high tungsten content in our area is associated with gold-tungsten mineralization characteristic of the high-temperature stage of the formation of the same ore formation, noted in Western Uzbekistan, in particular at the Charmitan ore field assigned to the goldtungsten industrial type by I.Kh. Khamrabaev (1971) and others.

Spectrographic aurometric surveying analysis (Table 3) showed that out of 40 samples submitted for analysis, the following samples showed high gold contents: Urt-213 - sulfidized granosyenite, the gold content reaches up to $71 \mathrm{~g} / \mathrm{t}$; Urt-248 - Albitized, highly sulfidized granite, $13 \mathrm{~g} / \mathrm{t}$; Urt-259 - porphyry granite interspersed with pyrite and vein arsenopyrite, $5.4 \mathrm{~g} / \mathrm{t}$; Urt-72 - silicified diorite with an ore vein of sphalerite, more than $3.0 \mathrm{~g}$ I t; Urt-228 - leucocratic, slightly berezitized granosyenite, $3.6 \mathrm{~g} / \mathrm{t}$; Urt-57 - a quartz vein in contact with solid ore of arsenopyrite and chalcopyrite, thickness about $1.2 \mathrm{~m}, 2 \mathrm{~g} / \mathrm{t}$; Urt220 - leucocratic granosyenite, 2 g / t; Urt-227 coarse granosyenite, $1.7 \mathrm{~g} / \mathrm{t}$; Urt-233 - albitized granite, $1.6 \mathrm{~g} / \mathrm{t}$; Urt-239 - potassium feldspar granosyenite, $1.7 \mathrm{~g} / \mathrm{t}$; Urt-302 - quartz vein, 1.2 $\mathrm{g} / \mathrm{t}$. In other samples, the gold content is insignificant, ranging from $0.01 \mathrm{~g} / \mathrm{t}$ and higher.

Table 3

The results of spectrochemical analysis to determine the mass fraction of gold $\mathrm{g} / \mathrm{t}$

\begin{tabular}{|c|c|c|c|c|c|}
\hline No. & Geologic No. & $\begin{array}{c}\text { Au g/t } \\
(\mathrm{ppm})\end{array}$ & No. & Geologic No. & $\begin{array}{c}\text { Au g/t } \\
\text { (ppm) }\end{array}$ \\
\hline 1 & URT- 46 & 0,02 & 21 & URT-220 & 2,0 \\
\hline 2 & URT- 47 & 0,04 & 22 & URT-225 & 0,71 \\
\hline 3 & URT- 48 & 0,03 & 23 & URT-227 & 1,4 \\
\hline 4 & URT- 49 & 0,01 & 24 & URT-228 & 3,6 \\
\hline 5 & URT- 55 & 0,01 & 25 & URT-233 & 1,6 \\
\hline 6 & URT- 56 & 0,1 & 26 & URT-235 & 0,92 \\
\hline 7 & URT- 57 & 2 & 27 & URT-237 & 33,0 \\
\hline 8 & URT- 60 & 0,06 & 28 & URT-238 & 3,4 \\
\hline
\end{tabular}


The American Journal of Social Science and Education Innovations (ISSN - 2689-100x)

Published: September 10, 2020 | Pages: 79-100

Doi: https://doi.org/10.37547/tajssei/Volumeo2Issueo9-12

2020: $5 \cdot 525$

\begin{tabular}{|c|c|c|c|c|c|}
\hline 9 & URT- 66 & 0,04 & 29 & URT-239 & 1,7 \\
\hline 10 & URT- 67 & 0,06 & 30 & URT-243 & 0,71 \\
\hline 11 & URT- 71 & 0,06 & 31 & URT-248 & 13,0 \\
\hline 12 & URT- 72 & 2,9 & 32 & URT-250 & 0,54 \\
\hline 13 & URT- 73 & 0,1 & 33 & URT-251 & 0,17 \\
\hline 14 & URT- 74 & 0,03 & 34 & URT-252 & 0,93 \\
\hline 15 & URT- 75 & 0,3 & 35 & URT-259 & 5,4 \\
\hline 16 & URT- 77 & 0,04 & 36 & URT-267 & 0,66 \\
\hline 17 & URT- 78 & 0,03 & 37 & URT-268 & 0,12 \\
\hline 18 & URT- 80 & 0,04 & 38 & URT-271 & 0,25 \\
\hline 19 & URT-213 & 71,0 & 39 & URT-276 & 0,18 \\
\hline 20 & URT-214 & 0,85 & 40 & URT-302 & 1,2 \\
\hline
\end{tabular}

Note: Analyzes were done by the Central Laboratory of the State Committee of Geology of the Republic of Uzbekistan. GRAND - POTOK atomic emission complex, Russian Federation, manufactured by VMK-Optoelectronics LLC, Novosibirsk, 2019. Analyst: Irgasheva R.A..

According to the above table of the results of mass spectrometric analysis (ISP) (Table 1), a high content of the following elements is observed in the Urt-72 sample: Au-92.9 g/t, Ag$450 \mathrm{~g} / \mathrm{t}, \mathrm{Ti}-820 \mathrm{~g} / \mathrm{t}, \mathrm{Ni}-40 \mathrm{~g} / \mathrm{t}$, Fe-73000 g/t, Ta$0.49 \mathrm{~g} / \mathrm{t}, \mathrm{W}-34 \mathrm{~g} / \mathrm{t}, \mathrm{Pt}-0.003 \mathrm{~g} / \mathrm{t}$. This sample is a silicified, sericitized diorite with an ore vein of sphalerite, hematite. A vein with a thickness of about $2.5 \mathrm{~cm}$ consists of magnetite and hematite. Figures 5, 6 show microscopic views of transparent and polished sections with petrographic and mineralogical descriptions.

The above mentioned mineral association in our sample was formed when the temperature of the hydrothermal solution of medium-low temperature conditions of the order of 300$150^{\circ} \mathrm{C}$ in the stability field of hematite [14]. 


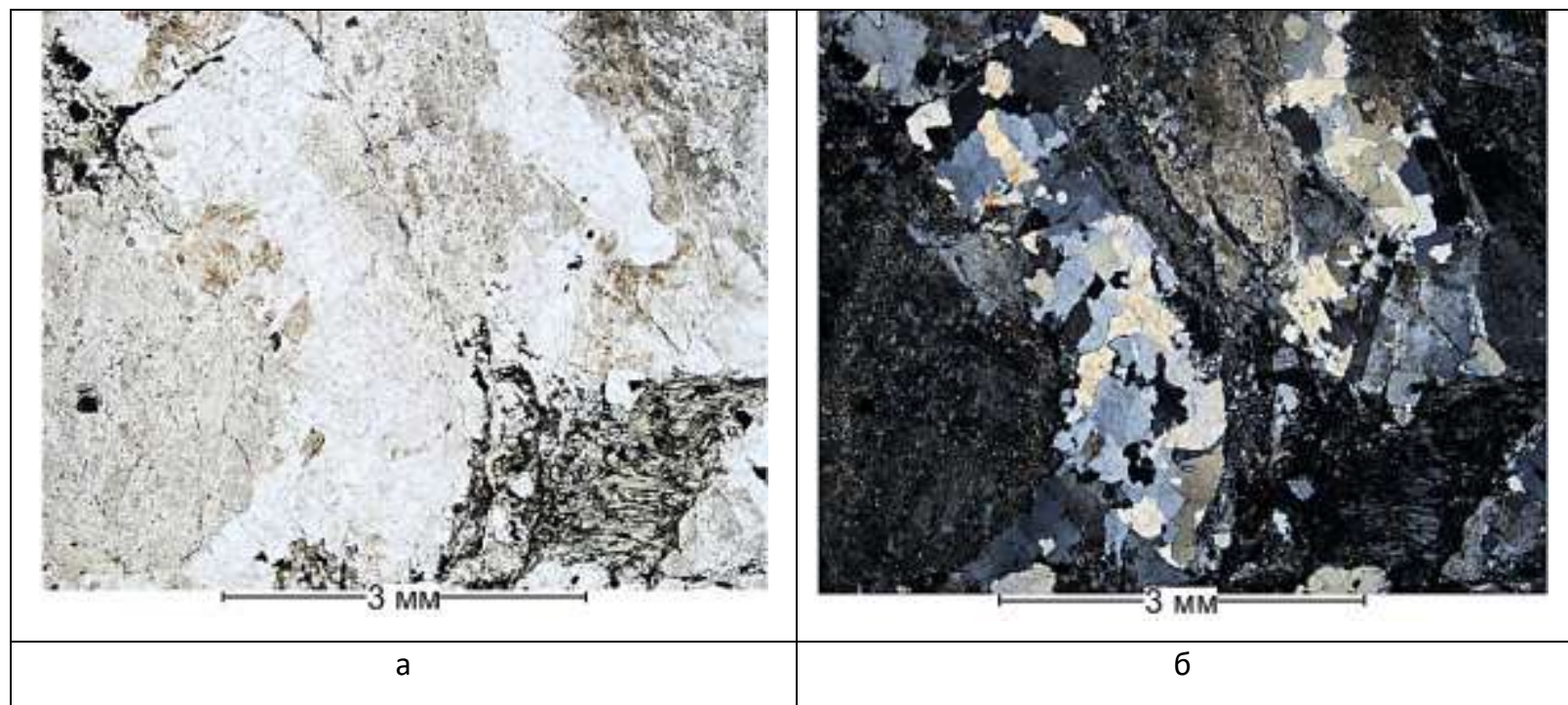

Fig. 5. Transparent thin section (sample Urt-72). Quartz diorite, undulose, sericitized: Fig. 5 / a - with one nickel, Fig. 5 / b - with two nicoles.

The mineral composition of quartz diorite (Urt72): plagioclase $60-65 \%$, quartz $10-15$, sericite 5 7, chlorite 3-5, carbonate 2-3, leukoxen 0.5-1, pyrite $0.5-1$, iron hydroxides of $0.5-0.7 \%$. The rock is undulose, and the ground mass of mineral grains plays the role of cement. The rock is composed of plagioclase, quartz, and chloritized biotite grains. Plagioclase is sericitized, carbonatized, and pelitized. Quartz forms irregular polygonal grains up to $2 \mathrm{~mm}$ in size. All biotite grains are chloritized with leucoxene cleavage cleavage, its relic remains are only occasionally observed. Carbonate forms thin short veins along cracks in the rock, with a thickness of up to $0.1 \mathrm{~mm}$ and a length of up to $1.7 \mathrm{~mm}$. 
The American Journal of Social Science and Education Innovations (ISSN - 2689-100x)

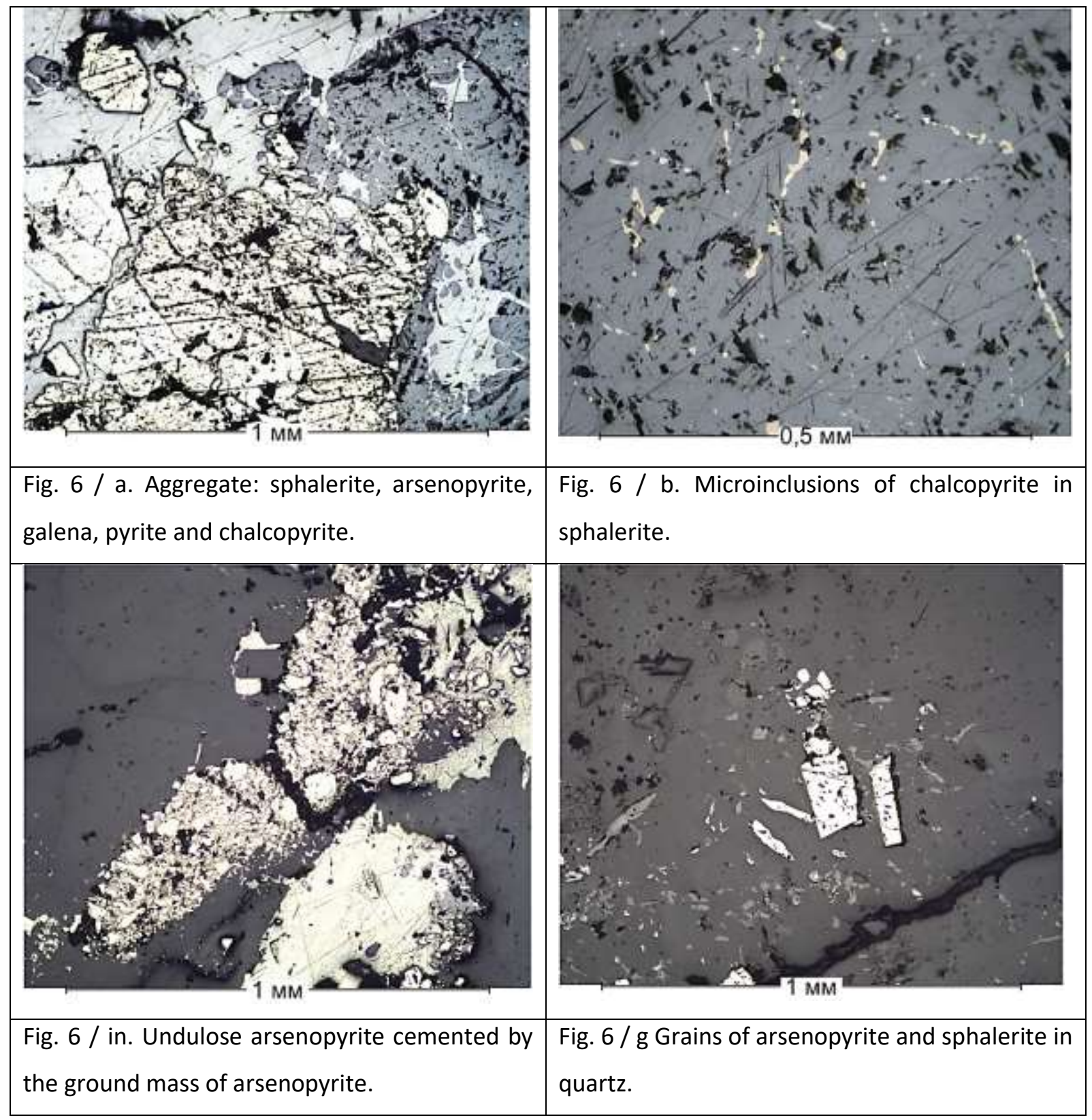

The mineral composition of the sample: Sphalerite 43-45, arsenopyrite 3-5, pyrite 1-1.5, galenite 3-5, chalcopyrite 1-1.5.

Ore minerals - sphalerite, arsenopyrite, pyrite, chalcopyrite and galena - are in close intergrowth with each other (Fig. $6 /$ a),

forming rather large disseminated aggregates of irregular shape.

Sphalerite forms a rather large discharge on the thin section, up to $1 \mathrm{~cm}$ thick. Its internal structure is cavernous, microinclusions of chalcopyrite are common everywhere (Fig. 6 / b), as well as galena, arsenopyrite and pyrite. 
Arsenopyrite grains are undulose, fragments are often stretched to a certain distance, and the gaps are filled with other minerals or ground mass of arsenopyrite (Fig. 6 / c).

Pyrite as well as arsenopyrite is undulose. Sometimes quartz inclusions are found in its grains.

Galena forms allotriomorphic secretions, with winding borders. In galena, like sphalerite, there are a large number of inclusions of other ore minerals, as well as rounded inclusions of quartz. It often contains "chipping triangles".

Arsenopyrite, sphalerite and chalcopyrite often form isolated precipitates and small aggregates in quartz (Fig. $6 /$ g). Chalkopyrite veins are branched, branched, sinuous, with a thickness of $0.015 \mathrm{~mm}$ and a length of $1.8 \mathrm{~mm}$.

The presence of hematite in this sample is an indication of a skarn contact-metasomatic nature similar to the banded metamorphosed chamosite ores of the Krivorozhsky type [14]. In case of hypergene argillization in our case, depending on the composition of the host rock, it is replaced by siderite, ankerite, limonite and other goethite hydroxides, hydrogetite, etc. Under hypogenous conditions, it turns into hydrochlorites such as thuringite, chabazite, and other smectite compounds, which contribute to the sorption accumulation of rare earth elements, which we mentioned earlier.

Thus, the content of iron-containing minerals in the COF is associated with autoskarns arising from a gradual decrease in temperature in medium temperature after the formation of rare-metal (W, Mo, Sn), neck-bearing skarns $[1,7]$, noted by Kh. Abdullaev (1947), I.Kh. Khamrabaev (1949, 1958) and others. The increased content of rare-earth elements in the described case reminds us of their identity with the unique skarn-iron ore-rare-earth deposit Bayan-Obo located in Inner Mongolia in northern China. It should be noted that light lanthanides of the cerium group prevailed on Bayan-Obo, and heavy lanthanides of the yttrium group, represented by ytterbium carbonates and other rare-earth elements, were developed in the COF in the Charmitan and Urtalik deposits.

\section{CONCLUSION}

In conclusion, it should be noted that the intensity of ore mineralization of the Uraltalik deposit is directly related to the near-ore metasomatically altered rocks of quartzfeldspar, skarn, listvenite-beresite, gumbaiteaesite formations of near-ore metasomatites of the acid leaching stage, which occurs after regional propylation contacting, apogranitic, greisenic, secondary quartzitic, hypogenousargillitized and other metasomatically altered rocks. With regional albitization, at the final stage of the propylitization process, a significant redistribution of ore-forming elements occurs at the deposit. This is due to the onset of processes of beresite-listvenitemetasomatic formation associated with the pre-ore deposition process. The polychronicity of the allocation of ore minerals causes a change in the associations of the latter depending on the physical-chemical conditions of ore formation in temperature, pressure, density of solutions, a change in the effective concentration and solubility of ore-forming elements. Strengthening the albitization of the aesite formation in local physical and mechanical tectonic situations, physical and mechanical properties as alkaline metasomatism, leads carriers of ore-forming minerals to hydrolysis and transfer of ore 
elements from them into hydrothermal solutions circulating in areas with high ore element contents. Aeration of such solutions over ore-bearing acidic rocks reduces the solubility of ore elements in accordance with the limits of changes in their effective concentrations and leads to ore deposition. This assumption is consistent with the actual data in the article.

\section{ACKNOWLEDGMENT}

These results are obtained on a framework applied project founded by the ministry of the innovative development Republic of Uzbekistan (contract No. П3-20170929154).

\section{REFERENCES}

1. Abdullaev Kh.M. Geology of scheelitiferous skarns of Central Asia. Tashkent, AN UzSSR publishsing house, 1947. - 399p.

2. Badalov S. T., Turesebekov A. Kh. Minerals-indicators of the hidden gold and sulfide mineralization of Karamazar // Russian Mineralogical Society. - 1981. - Part 110. Issue 7. -17618opp.

3. Dautov A.I., Asatullaev N.R. New data on the structure of the Koshrabad intrusion // Uzbek geological magazine - 1971. - No.4. -70-74pp.

4. Ivankin P.F., Nazarova N.I. Methodology for the study of orebearing structures in terrigenous strata. Moscow, Nedra Publishing House, 1988. - 254pp.

5. Konopelko D.L., Biske Yu.S., Kullerud K., Zeltmann P., Divaev F.K. Koshrabad granite massif in Uzbekistan: petrogenesis, metallogeny and the geodynamic setting // Geology and geophysics. - 2011. Vol. 52, - No. 12. 1987-2000pp.

6. Musaev A.M., Djumaniyazov D.I. Sodic alteration as a REE concentration factor in granosyenites of the Urtalik deposit of the Charmitansky ore field // Geologic bulletin of Uzbekistan. - 2019. - No. 1. -39-41pp.

7. Musaev A.M., Djumaniyazov D.I, Nemattulaev S.Yu. Metasomatic formations of gold deposits of the Charmitan ore field // Geology and mineral resourses. - 2019. - No. 3. -2731pp.

8. Musaev A.M., Mirzaev A.U., Dostkulov Sh.Ya, Musaev R.A. Rare-earth minerals of the Charmitan ore field, their genetic types and industrial importance // Materials of the Republican scientific conference "Modern problems of the connection of geodynamics, magmatism and mineralization". Tashkent, 2012 . - 127-132pp.

9. Musaev A.M., Nemattulaev S.Yu, Djumaniyazov D.I., Hushvakov A.B. To the geochemistry of the Urtalik deposit (northern Nuratau) // International Conference of Young Scientists "Science and Innovation" dedicated to pressing problems of the development of science and innovative processes. Tashkent, 2019. - 186-187pp.

10. Musaev A.M., Nemattulaev S.Yu, Djumaniyazov D.I, Hushvakov A.B., Karimova F.B. Geochemical features of rocks of the Urtalik deposit (northern Nuratau) // International Scientific Conference "The Contribution of the Outstanding Kazakhstan Scientist Professor P.T. Tazhibayeva in the 
development of geological science of Kazakhstan". - Almaty, 2019. 255262pp.

11. Paramonov Yu.I., Akhmedov N.A. Ore deposits of Uzbekistan. - Tashkent, 2001. - 202-211pp.

12. Tillyaev Kh.S., Asatullayev I.R., Kushmuradov O.K. New data on the geology of the Charmitan gold ore deposit // Scientific works of $\mathrm{T}$. university. -1974. - Vol. 438. - 95-99pp.

13. Tulegenov T.Dj., Pirnazarov M.M., Khamiddulaev N.F., Khamroev I.O. Ore metasomatites of the deep horizons of the Charmitan deposit and their exploratory significance // Geology and mineral resourses. -1999. - No. 5. - 2023pp.

14. Khamrabaev I.Kh. About new types of tungsten ores in Western Uzbekistan // Uzbek geological magazine - 1972. No. 4. - 3-7pp.

15. Khamrabaev I.Kh. Magmatism and post-magmatic processes in Western Uzbekistan. - Tashkent, AN UzSSR publishsing house, 1958. - 452p.

16. Khamrabaev I.Kh., Chebotaryev G.M., Mansurov M.M., Tillyaev Kh.S., Dautov A.I., Khrenov V.A. Some geological and mineralogical features of the Charmitan gold deposit in Western Uzbekistan // Uzbek geological magazine - 1971. - No. 3. - 3-7pp.

17. Khorvat V.A., Bertman E.B., Khamrabaev I.Kh., Chebotaryev G.M., Semenova T.V., Chernyavsky Yu.A., Tillyaev Kh.S. The near-vein metasomatic rocks of the Charmitan deposit (Western Uzbekistan) // Metallogeny and geochemistry of Uzbekistan. - Tashkent, “Fan"
Publishing House, UzSSR. - 1974. - 6168pp.

18. Khorvat V.A., Khrenov V.A. Metasomatic rocks of the Charmitan gold deposit and their search value // DAN UzSSR. - 1975. - No. 4.

19. Scherban I.P., Tsoy R.V., Ivanov I.P. Near-ore metasomatites of Western Uzbekistan. - Moscow, Nauka Publishing House. - 1990. - 191p.

20. Yudalevich Z.A., Sandomirsky G.G., Nikanorov G.S. On the gold content in granitoids and quartz veins of Northern Nuratau and Bukantau // Uzbek geological magazine -1973. - No. 5. -1722pp. 